\title{
PERFORMA TES CEPAT MOLEKULER DALAM DIAGNOSA TUBERKULOSIS DI BALAI BESAR KESEHATAN PARU MASYARAKAT MAKASSAR
}

\author{
Nurlia Naim ${ }^{1}$, Novi Utami Dewi ${ }^{2}$ \\ 1,2 Jurusan Analis Kesehatan Poltekkes Makassar \\ Koresponden : nurlianaim0416@gmail.com
}

\begin{abstract}
ABSTRAK
Mycobacterium tuberculosis merupakan salah satu bakteri patogen intrasel yang menimbulkan penyakit tuberkulosis (TB). Tes cepat molekuler (TCM) merupakan metode penemuan terbaru untuk diagnosis TB berdasarkan pemeriksaan molekuler yang menggunakan metode Real Time Polymerase Chain Reaction Assay (RT-PCR) semi kuantitatif yang menargetkan wilayah hotspot gen rpoB pada Mycobacterium tuberculosis (MTB), yang terintegrasi dan secara otomatis mengolah sediaan dengan ekstraksi deoxyribo nucleic acid (DNA) dalam cartridge sekali pakai. penelitian ini bertujuan untuk menganalisa performa tes cepat molekuler dalam diagnosis tuberkulosis. Penelitian yang dilakukan adalah penelitian cross sectional study dengan teknik pengambilan sampel secara purposive sampling sebanyak 111 sampel di Balai Besar Kesehatan Paru Masyarakat Makassar. Hasil Uji TCM didapatkan sensitivitas sebesar 73,33\%, spesifitas 90,12\%, Nilai Ramal Positif (NRP) 73,33\% dan Nilai Ramal Negatif (NRN) 76,86\% dalam mendeteksi MTB dan pada Uji Wilcoxon didapatakan nilai signifikansi $(\mathrm{p})$ sebesar $0,920(\mathrm{P}>0,05)$ yang berarti tidak terdapat perbedaan yang signifikan antara metode TCM dengan metode gold standar kultur. TCM memiliki sensitivitas sebesar 89,47\%, spesifitas 25\%, Nilai Ramal Positif (NRP) 85\% dan Nilai Ramal Negatif (NRN) 33,33\% dalam deteksi resistensi rifampisin dan pada Uji Fishers Exact didapatkan nilai signifikansi 0,453 yang lebih besar dari $0,05(\mathrm{P}>0,05)$ yang berarti tidak terdapat perbedaan yang signifikan antara TCM dengan metode proporsi. Disimpulkan bahwa TCM memiliki nilai spesifisitas yang tinggi untuk mendeteksi MTB sehingga dapat digunakan dalam diagnosis tuberkulosis dan memiliki nilai sensitifitas yang tinggi untuk digunakan sebagai alat screening uji resistensi terhadap Rifampisin.
\end{abstract}

Kata kunci : Performa Tes Cepat Molekuler , Diagnosis, Tuberkulosis

Pendahuluan

Mycobacterium tuberculosis

merupakan salah satu bakteri patogen intrasel yang menimbulkan penyakit tuberkulosis (TB). Tuberkulosis (TB) merupakan salah satu penyakit yang 
telah lama dikenal dan sampai saat ini masih menjadi penyebab utama kematian di dunia (Saptawati L, et al 2012).

World Health Organization (WHO) melaporkan bahwa sebanyak 10,4 juta orang jatuh sakit dengan TB, dan 1,7 juta orang meninggal karena penyakit ini (termasuk 0,4 juta di antara orang dengan HIV). Lebih dari 95\% kematian akibat TB terjadi di negara berpenghasilan rendah dan menengah. Tujuh negara menyumbang $64 \%$ kasus TB baru : India, Indonesia, China, Filipina, Pakistan, Nigeria, dan Afrika Selatan (WHO,2016)

Diagnosis TB paru ditegakkan berdasarkan gambaran klinis, pemeriksaaan fisik, gambaran radiologis, pemeriksaan laboratorium, dan uji tuberculin. Diagnosis TB paru yang digunakan saat ini secara rutin di laboratorium termasuk rumah sakit dan puskesmas adalah diagnosis bakteriologis dengan teknik mikroskopis basil tahan asam (BTA). (Lynda A,2012)

Tes cepat molekuler merupakan metode penemuan terbaru untuk diagnosis TB berdasarkan pemeriksaan molekuler yang menggunakan metode Real Time Polymerase Chain Reaction Assay (RT-PCR) semi kuantitatif yang menargetkan wilayah hotspot gen rpoB pada Mycobacterium tuberculosis, yang terintegrasi dan secara otomatis mengolah sediaan dengan ekstraksi deoxyribo nucleic acid (DNA) dalam cartridge sekali pakai. Penelitian invitro menunjukkan batas deteksi bakteri TB dengan metode RT-PCR GeneXpert minimal 131 bakteri/ml sputum. Waktu hingga didapatkannya hasil kurang dari dua jam dan hanya membutuhkan pelatihan yang simpel untuk dapat menggunakan alat ini. (Kurniawan et al,2016)

Pemanfaatan penggunaan alat tes cepat GeneXpert MTB/RIF saat ini ditujukan untuk diagnosis terduga TB resisten obat (Manajemen Terpadu Pengendalian TB Resisten Obat/MTPTRO), TB-HIV, dan selanjutnya akan dikembangkan untuk diagnosis TB baru pada anak, TBDiabetes Melitus, TB ekstra paru, serta diagnosis pada terduga TB hasil BTA negatif.(Kemenkes, 2016) Metode tes cepat molekuler terus dikembangkan dan akan dilakukan untuk diagnosis tuberkulosis dimasa yang akan datang sehingga perlu dilakukan uji performa tes cepat molekuler ini khususnya di Balai Besar Kesehatan Paru Masyarakat Makassar.

\section{METODE}

Penelitian ini merupakan cross sectional study dan dilakukan setelah mendapatkan rekomendasi dari komisi etik Penelitian Kesehatan Politeknik Kesehatan Makassar dan persetujuan tindakan medik (informed consent) dari pasien. Populasi adalah pasien yang 
menderita penyakit tuberkulosis di Balai Besar Kesehatan Paru Masyarakat Makassar. Sampel adalah penderita yang memenuhi kriteria inklusi dan ekslusi. Besar sampel ditentukan dengan menggunakan rumus :

$$
n=\frac{\mathrm{N}}{1+N\left(d^{2}\right)}
$$

Keterangan :

$\mathrm{N}$ : Besar Populasi

$\mathrm{n}$ : Besar Sampel

$\mathrm{d}$ : Tingkat kesalahan yang digunakan $5 \%$

jumlah sampel minimal sebanyak 109,09 dan dibulatkan menjadi 110 orang.

Kriteria inklusi yaitu penderita tuberkulosis paru, sampel yang termasuk dalam kategori $9+1$ kriteria pemeriksaan tes cepat molekuler (Suspect TB-MDR) berdasarkan SOP BBBKPM Makassar, bersedia menjadi subjek penelitian dibuktikan dengan informed consent, volume bahan pemeriksaan (sputum) mencukupi untuk dijadikan pemeriksaan, dan sampel atas dasar rujukan dokter untuk dilakukan pemeriksaan TCM.

Semua penderita suspect TB-MDR dilakukan pemeriksaan MTB menggunakan metode tes cepat molekuler, metode BTA dekontaminasi, dan metode kultur dengan menggunakan media Lownstein Jensen sebagai Gold Standar. Spesimen sputum yang sudah dikumpulkan dan dimasukkan kedalam wadah lalu dilakukan pemeriksaan BTA dekontaminasi metode kubica, tes cepat molekuler dengan menambahkan buffer kemudian diinkubasi selama 15 menit lalu diambil dengan pipet khusus dan dimasukkan kedalam cartridge, setelah itu dimasukkan kedalam alat GeneXpert MTB/RIF. Sputum diproses dan diperiksa oleh GeneXpert MTB/RIF secara otomatis, hasilnya diperoleh setelah \pm 2 jam. Kemudian sisa sputum yang tidak digunakan di masukkan kedalam tabung falcon lalu ditambahkan dengan $\mathrm{NaOH} 4 \%$ dan PBS (Phospat Buffer Sulfat) lalu di sentrifugasi. Dari hasil sentrifugasi, sputum diinokulasikan untuk penanaman pada media Loweinstein Jensen lalu dïnkubasi pada suhu $37^{\circ} \mathrm{C}$. Hasil penanaman di media Loweinstein Jensen diperoleh setelah 6-8 minggu. Kemudian dari hasil kultur yang positif dilakukan uji resistensi menggunakan metode gold standar proporsi

\section{HASIL}

Penelitian ini didapatkan data hasil pemeriksaan Laboratorium dengan melakukan pemeriksaan Mycobacterium tuberculosis metode tes cepat molekuler (TCM), dekontaminasi, dan Kultur. Setelah selama kurun waktu 3 bulan didapatkan 111 subjek. Data diatribusi dan frekuensi subjek berupa hasil BTA dekontaminasi, tes cepat molekuler, dan kultur. 
Tabel 1. Distribusi dan Frekuensi hasil pemeriksaan BTA Dekontaminasi

\begin{tabular}{lcc}
\hline & Frekuensi & Persen \\
\hline Negatif & 91 & $82 \%$ \\
\hline Positif 1 & 6 & $5,4 \%$ \\
\hline Positif 2 & 7 & $6,3 \%$ \\
\hline Positif 3 & 7 & $6,3 \%$ \\
\hline Total & 111 & $100 \%$ \\
\hline
\end{tabular}

Pada tabel 1 terlihat dari 111 jumlah sampel penelitian yang dilakukan hasil pemeriksaan BTA dekontaminasi menunjukkan hasil negatif sebanyak
91 sampel, positif $1(+1)$ sebanyak 6 sampel, positif 2 dan $3(+2 \&+3)$ masing-masing 7 sampel

Tabel 2. Distribusi Frekuensi hasil pemeriksaan MTB dengan metode TCM

\begin{tabular}{ccc}
\hline & Frekuensi & Persen \\
\hline Negatif & 81 & $73 \%$ \\
Rendah & 3 & $2,7 \%$ \\
Sedang & 15 & $13,5 \%$ \\
Tinggi & 12 & $10,8 \%$ \\
\hline Total & 111 & $100 \%$ \\
\hline
\end{tabular}

Pada Tabel 2 hasil tes cepat molekuler menunjukkan hasil negatif 81 sampel, positif rendah 15 sampel, positif sedang

sebanyak 3 sampel dan positif Tinggi sebanyak 12 sampel.

Tabel 3. Distribusi Frekuensi hasil pemeriksaan MTB dengan metode gold standar kultur

\begin{tabular}{ccc}
\hline & Frekuensi & Persen \\
\cline { 2 - 4 } Negatif & 81 & $73 \%$ \\
Positif 1 & 17 & $15,3 \%$ \\
Positif 2 & 6 & $5,4 \%$ \\
Positif 3 & 7 & $6,3 \%$ \\
\hline Total & 111 & $100 \%$ \\
\hline
\end{tabular}

Pada Tabel 3 hasil kultur menunjukkan hasil negatif sebanyak 81 sampel, positif $1(+1)$ sebanyak 17 sampel, positif $2(+2)$ sebanyak 6 sampel dan positif $3(+3)$ sebanyak 7 sampel. 
Tabel 4. Perbandingan hasil deteksi MTB metode TCM dengan gold standard metode kultur

\begin{tabular}{lr}
\hline & Hasil Deteksi \\
\hline Mann-Whitney $U$ & 6123.000 \\
Wilcoxon $W$ & 12339.000 \\
$\mathrm{Z}$ & -.101 \\
Signifikansi & .920 \\
\hline a. Variabel grup: Jenis Metode & \\
\hline
\end{tabular}

Pada Tabel 4 diketahui bahwa nilai dapat disimpulkan tidak terdapat signifikansi (p) sebesar 0.920 yang perbedaan yang signifikan antara mana lebih besar dari batas kritis yang metode TCM dengan kultur. ditetapkan yaitu $0.05(\mathrm{p}>0.05)$. Maka

Grafik.1 Histogram perbandingan metode TCM dengan gold standard kultur

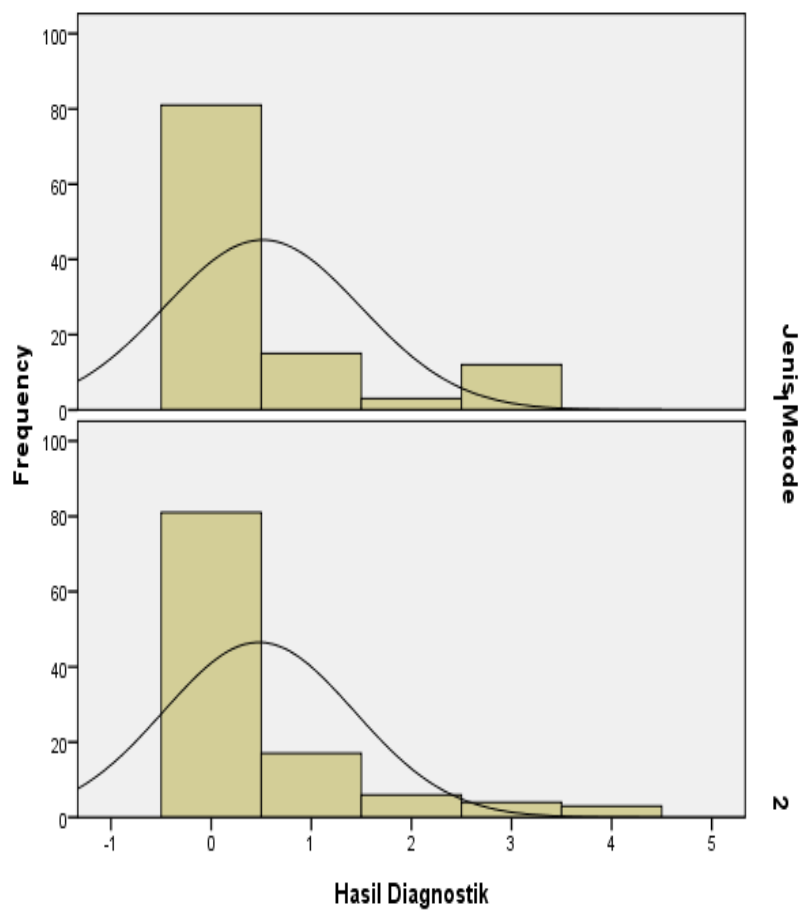

Berdasarkan Grafik 1 di atas, nilai tengah atau median antara dua kelompok yaitu sama (berada antara 0 dan 1). Hal ini membenarkan hasil pada
Tabel 4 sebelumnya bahwa antara dua kelompok metode tidak terdapat perbedaan yang signifikan. 
Tabel 5. Distribusi frekuensi deteksi MTB metode Dekontaminasi dengan metode gold standar kultur

\begin{tabular}{cccrr}
\hline \multirow{2}{*}{ Hasil } & & \multicolumn{3}{c}{ Gold standar } \\
& & Positif & Negatif & Total \\
\hline Metode & Positif & 16 & 4 & 20 \\
Dekontaminasi & Negatif & 14 & 77 & 91 \\
\hline Total & & 30 & 81 & 111 \\
\hline
\end{tabular}

Berdasarkan Tabel 5 di atas, diperoleh nilai sensitivitas sebesar 53,30\%, spesifisitas $95,06 \%$, nilai ramal positif

Tabel 6. Distribusi frekuensi pemeriksaan MTB metode TCM dengan Metode gold standar

\begin{tabular}{ccccc}
\hline \multirow{2}{*}{ Hasil } & \multicolumn{4}{c}{ Kultur } \\
& & Positif & Negatif & Total \\
\hline Metode & Positif & 22 & 8 & 30 \\
TCM & Negatif & 8 & 73 & 81 \\
\hline \multicolumn{2}{c}{ Total } & 30 & 81 & 111 \\
\hline
\end{tabular}

Berdasarkan Tabel 6 di atas, diperoleh nilai sensitivitas sebesar $73,33 \%$, spesifisitas $90,12 \%$, nilai ramal positif

Tabel 7. Distribusi frekuensi Uji resistensi metode TCM dengan Metode gold

\begin{tabular}{|c|c|c|c|c|}
\hline \multirow{2}{*}{ Hasil } & \multicolumn{4}{|c|}{ Gold standar } \\
\hline & & Sensitif & Resisten & Total \\
\hline \multirow{2}{*}{$\begin{array}{c}\text { Metode } \\
\text { TCM }\end{array}$} & Sensitif & 17 & 3 & 20 \\
\hline & $\begin{array}{c}\text { Resiste } \\
\mathrm{n}\end{array}$ & 2 & 1 & 3 \\
\hline \multicolumn{2}{|c|}{ Total } & 19 & 4 & 23 \\
\hline
\end{tabular}

Berdasarkan Tabel 6 di atas, didapatkan nilai sensitivitas sebesar $89,47 \%$, spesifisitas $25 \%$, nilai ramal positif
(NRP) $73,33 \%$, dan nilai ramal negatif (NRN) 76,86\%.
(NRP) $80 \%$, dan nilai ramal negatif (NRN) $84,61 \%$. 
Tabel 8. Hasil uji Chi-square proporsi resistensi metode TCM dengan gold standar

\begin{tabular}{|c|c|c|c|c|c|}
\hline & Nilai & $\mathrm{df}$ & $\mathrm{p}$ & $\begin{array}{c}\text { Fisher' } \\
\text { s exact } \\
(2 \text { sisi) }\end{array}$ & $\begin{array}{c}\text { Fisher } \\
\text { s exact } \\
\text { (1 sisi) }\end{array}$ \\
\hline $\begin{array}{c}\text { Chi- } \\
\text { square }\end{array}$ & $0.610^{\mathrm{a}}$ & 1 & $\begin{array}{c}0.43 \\
5\end{array}$ & & \\
\hline $\begin{array}{c}\text { Chi- } \\
\text { square } \\
(2 \times 2)\end{array}$ & 0.000 & 1 & $\begin{array}{c}1.00 \\
0\end{array}$ & & \\
\hline $\begin{array}{c}\text { Fisher's } \\
\text { exact }\end{array}$ & & & & 0,453 & 0.453 \\
\hline $\begin{array}{c}\text { a. 3 sel (75,0\%) mempunyai nilai ekspektasi } \\
\text { kurang dari 5. }\end{array}$ \\
\hline
\end{tabular}

Dari Tabel 8 di atas, didapatkan nilai signifikansi hasil uji chi-square sebesar 1 (untuk tabel 2x2). Namun karena terdapat nilai ekspektasi yang kurang dari 5 yaitu sebesar $75 \%$ (atau lebih dari 20\%), maka digunakan uji Fisher's exact. Berdasarkan uji tersebut, didapatkan nilai signifikansi yaitu 0.453 yang lebih besar dari 0.05 ( $\mathrm{p}>0.05)$, maka dapat disimpulkan tidak terdapat perbedaan yang signifikan antara proporsi resistensi metode TCM dengan kultur.

\section{Pembahasan}

Dalam mendeteksi MTB menggunakan memiliki sensitivitas 73,33\%, spesifitas 90,12\%, Nilai Ramal Positif (NRP) 73,33\% dan Nilai Ramal Negatif (NRN) 76,86\% dan pada Uji Wilcoxon didapatakan nilai signifikansi (p) sebesar 0,920 $(\mathrm{P}>0,05)$ yang berarti tidak terdapat perbedaan yang signifikan antara metode TCM dengan kultur, sehingga metode TCM dapat digunakan untuk diagnosis tuberkulosis karena didapatkan hasil nilai spesifisitas yang tinggi artinya metode ini mampu mendeteksi $90,12 \%$ pasien yang tidak terinfeksi MTB dari keseluruhan pasien yang benar-benar tidak terinfeksi, sehingga metode ini efektif digunakan sebagai alat diagnosis MTB. Dalam uji resistensi metode TCM memiliki sensitivitas sebesar 89,47\%, spesifitas 25\%, Nilai Ramal Positif (NRP) $85 \%$ dan Nilai Ramal Negatif (NRN) 33,33\% dan pada Uji Fishers Exact didapatkan nilai signifikansi 0,453 yang lebih besar dari 0,05 ( $\mathrm{P}>$ $0,05)$ yang berarti tidak terdapat perbedaan yang signifikan antara TCM dengan metode proporsi namun metode TCM memiliki spesifisitas $25 \%$ yang artinya hanya dapat mendeteksi pasien resisten $25 \%$ dari keseluruhan pasien yang benar-benar resisten sehingga TCM dapat digunakan untuk screening uji resistensi terhadap 
Rifampisin karena didapatkan hasil nilai sensitivitas yang tinggi.

Pada pemeriksaan BTA metode dekontaminasi pada penelitian ini memiliki spesifisitas 95,06\% dibandingkan dengan metode gold standar kultur namun untuk sensitifitasnya lebih rendah dibandingkan dengan metode TCM yaitu 53,30\% dibanding TCM yaitu $73,33 \%$ hal ini dapat disimpulkan bahwa TCM lebih baik dalam mendeteksi pasien yang benar-benar terinfeksi MTB dibandingkan dengan BTA dekontaminasi dan seperti pada penelitian Bahtiar sebelumnya bahwa BTA memiliki kelemahan dikarenakan pemeriksaan mikroskopis BTA metode dekontaminasi memerlukan volume specimen yang cukup banyak yaitu sekitar $2-4 \mathrm{ml}$ sputum agar menemukan Mycobacterium tuberculosis dalam sputum lebih mudah, hal ini berguna untuk kasus tuberkulosis dengan jumlah bakteri yang sedikit. Namun hal ini menjadi sulit dikerjakan apabila jumlah specimen sputum yang didapat sedikit atau kurang dari $2 \mathrm{ml}$ (Bahtiar Z, 2016). Penelitian ini sejalan dengan penelitian Dhingra VK et al (2003) menilai validitas dan reliabilita pemeriksaan BTA sputum dibandingkan dengan kultur pada media Loweinstein Jensen terhadap 5776 pasien tuberkulosis paru. Didapatkan sensitivitas dan spesifisitas pemeriksaan BTA sputum sebesar $62 \%$ dan $99 \%$ dengan nilai prediksi positif $96,4 \%$ dan nilai prediksi negatif $84,2 \%$.

Hasil penelitian ini sejalan dengan penelitian yang menyatakan pemeriksaan basil tahan asam metode tes cepat molekuler memiliki sensitivitas yang bagus, dimana pada tes cepat molekuler bisa membaca kuman Mycobacterium tuberculosis serta dapat membaca resistensi rifampisin secara bersamaan, (Susanty E, 2015 ; Kurniawan E dkk, 2016), namun pada penelitian selain sensitifitas yang baik diketahui pula metode TCM memiliki spesifisitas yang tinggi dalam mendeteksi MTB

Proses tes cepat molekuler menggunakan molecular beacon dengan target gen rpoB dan mendeteksi 81 bp (base pair) core region dari gen rpoB yang dikode oleh lokasi aktif enzim. Core region rpoB terletak di samping Mycobacterium tuberculosis dengan urutan DNA spesifik. Oleh karena itu, sangat memungkinkan untuk mendeteksi Mycobacterium tuberculosis dan resistensi rifampisin secara bersamaan dengan menggunakan teknologi PCR. Molecular beacon merupakan urutan oligonukleotida yang berisi urutan probe yang terdapat diantara dua tangkai urutan DNA. Molecular beacon digunakan untuk mendeteksi keberadaan Mycobacterium tuberculosis dan mendiagnosa resistensi rifampisin secara bersamaan. Molecular beacon menggunakan fluorophor dan quencher untuk mendeteksi hibridisasi pada masingmasing dari lima region target amplifikasi gen (Association of Public Health Laboratories, 2013). Untuk uji resistensi dari hasil penelitian ini masih disimpulkan dapat digunakan sebagai screening karena memiliki sensitifitas 
yang tinggi dan memerlukan penelitian lebih lanjut.

\section{Kesimpulan}

Metode Tes Cepat Molekuler (TCM) memiliki nilai spesifisitas yang tinggi untuk mendeteksi MTB sehingga dapat digunakan dalam diagnosis tuberkulosis dan memiliki nilai sensitifitas yang tinggi untuk digunakan sebagai alat screening uji resistensi terhadap Rifampisin.

Saran

Berdasarkan kesimpulan diatas, maka penulis dapat memberikan saran yaitu,

1. Metode TCM digunakan dalam identifikasi MTB dalam penegakkan diagnosis tuberkulosis karena hasil lebih cepat diperoleh dan memiliki sensitifitas dan spesifisitas yang baik

2. Diharapkan pada peneliti selanjutnya mengkaji metode TCM dalam uji resistensi terhadap rifampisin menggunakan jumlah sampel yang lebih banyak dibandingkan dengan metode gold standar.

\section{Ucapan Terima Kasih}

Terima kasih kepada semua pihak yang telah membantu dalam penelitian ini.

\section{Daftar Pustaka}

Acharya S, Ghimire P, Khadka D.K, Nepali S. (2010). Comparison of Proportion and Resistance Methods for Drug Susceptibility Testing of Mycobacterium Tuberculosis Centre Nepal.
SAARC Journal of Tuberculosis Lung Disease \& HIV/AIDS 1 Adriyani, A. (2016). Gambaran Hasil Perbandingan Pemeriksaan Mikroskopis Basil Tahan Asam Dengan Carbol Fuchsin Dan Methylene Blue. Retrieved Desember 14, 2017, from repository.unimus.ac.id/110/1/S

KRIPSI\%20FULTEX.pdf

Alsagaff, H., \& Mukty, H. A. (2010). Dasar-dasar Ilmu Penyakit Paru. Surabaya: Airlangga University Press.

Amran, P., Mursalim, Hadijah, S., \& Hasnawati. (2015). Bakteriologi Terapan 3. Makassar: Kementerian Kesehatan RI Politeknik Kesehatan Kemenkes Makassar.

Association of Public Health Laboratories. (2013). Laboratory Considerations for Use of Cepheid Xpert MTB/RIF Assay. Retrieved Juni 25, 2018, from . www.aphl.org/AboutAPHL/publ ications/Documents/ID_2013No $\mathrm{V}$ Cepheid-Xpert-FactSheet.pdf.

Bahtiar, Z. (2016). Perbandingan Hasil Pemeriksaan Basil Tahan Asam Menggunakan Mikroskopis Langsung (Direct) Dengan Metode Kubica (Indirect). Retrieved Desember 14, 2017, from

http://zulfitriani28.blogspot.co.id /2017/03/karya-tulis-ilmiahperbandingan-hasil.html

Brooks, G. F., Carrol, K. C., Butel, J. S., Morse, S. A., \& Mietzner, T. A. (2014). Jawetz, Melnick, \& 
Adelberg Mikrobiologi Kedokteran. Jakarta: Penerbit Buku Kedokteran ECG.

CDC (Central of Disease Control). (2009) Updated Guildelines for the Use of Nucleic Acid Amplification Tests in the Diagnosis of Tuberculosis. MMWR. Retrieved Juni 25, 2018, from www.cdc.gov/mmwr/preview/m mwrhtml/mm5801a3. htm?scid=mm5801a3_e.

Frida, E., S, I., \& Hardjoeno. (2006). Analisis Temuan BTA pada Sputum Cara Langsung dan Sediaan Konsentrasi Pada Suspek TB. Retrieved Juni 25, 2018 from journal.unair.ac.id/downloadfullpapers-IJCPML-12-2-05.pdf.

Gampa, E. S. (2017). Analisis Hubungan Gradasi Basil Tahan Asam Dengan Indeks Eritrosit Pada Penderita Tuberculosis Diagnosis Awal Di BBKPM Makassar.

Kementerian Kesehatan RI. (2012). Standar Prosedur Operasional Pemeriksaan Mikroskopis TB. Retrieved Desember 14, 2017, from

www.depkes.go.id/download.ph $\mathrm{p}$ ?file $=$ download/.../SopTB/SopT B-2012-TB.pdf

Kementerian Kesehatan RI. (2016). Info Data Tuberkulosis Indonesia. Retrieved Desember 14, 2017, from www.depkes.go.id/download.ph $\mathrm{p}$ ?file=download/.../infodatin/In foDatin-2016-TB.pdf
Kurniawan, E., Raveinal, Fauzar, \& Arsyad, Z. (2016). Nilai Diagnostik Metode Real Tme PCR GeneXpert Pada Tuberkulosis Paru BTA Negatif. Retrieved Desember 12, 2017, from jurnal.fk.unand.ac.id/index.php/j $\mathrm{ka} /$ article/download/609/495

Lynda, A. (2012). Rapid TB Test. Jurnal Tuberkulosis Indonesia. Retrieved Desember 12, 2017, from ppti.info/ArsipPPTI/PPTIJurnal-Maret-2012.pdf

Saptawati, L., Mardiastuti, Kurniawati, A., \& Rumende, C. M. (2012). Evaluasi Metode FastPlaque Tuberkulosis Untuk Mendeteksi Mycobacterium Tuberculosis Pada Sputum Di Beberapa Unit Pelayanan Kesehatan Di Jakarta . Jurnal Tuberkulosis Indonesia. Retrieved from ppti.info/ArsipPPTI/PPTI-JurnalMaret-2012.pdf

World Health Organization. (2016). Tuberculosis. Retrieved Desember 14, 2017, from www.who.int/tb/...report/gtbr2 016_executive_summary.pdf 